\title{
Emotional and Aesthetic Labor of Finnish Military Officers'
}

\section{Suvi Kouri²}

Doctoral researcher, University of Jyväskylä, Department of Social Sciences and Philosophy, Finland

\begin{abstract}
This study analyzes the emotional and aesthetic labor of Finnish military officers. It examines the kinds of valuations officers attach to the notion of an ideal soldier. The meanings that officers give to these ideals are explored within the wider framework of post-Fordist new work. The ideal soldier is traditionally considered to be physically capable and strong, rational, and in control-features culturally coded as masculine. An analysis of 108 military officers' writings and 12 interviews showed that while the traditional masculine ideal still exists, a vast variety of valuations are related to new work. The notion of the new ideal worker includes attributes, such as empathy, emotional intelligence, and social skills, which are culturally coded as feminine qualities. These feminine valuations may work to female officers' advantage. However, despite fractures in traditional masculine ideals, there are still some deeply rooted gender stereotypes that work to female officers' disadvantage.
\end{abstract}

\section{KEYWORDS}

Aesthetic labor / emotional labor / female officers / ideal soldier / military

\section{Introduction}

orking life in postmodern society has been and is in motion. The concept of postFordist new work has been incorporated into debates about changing working life (e.g., Castells 1996; Gibson-Graham 1996). According to theoretical understanding, new work is subjectivated, informatized, affective, interactive, communicative, and feminized work (Adkins \& Jokinen 2008; McDowell 2009). The new ideals of working life now include embodied attributes and emotions in workplace performance to an increasing extent, even in workplaces that are not typically considered service work (McDowell 2009; Parviainen et al. 2016). According to Parviainen et al. (2016), a new kind of service attitude is required from employees in a great variety of professions. Affective and intimate skills, such as care, emotion, embodiment, and aesthetics, which are usually associated with women and private life, are enacted routinely in working life (Hochschild 1983; Lewis \& Simpson 2007). The feminization of work creates possibilities to perform femininities and masculinities strategically regardless of gender (Adkins 2002; McDowell 1997). According to Adkins (ibid.), the conventional ideals of working life, such as the rational and disembodied employee, used to work to men's advantage and women's disadvantage. These ideals are being replaced by embodied workplace performance, which is required from both sexes.

\footnotetext{
${ }^{1}$ You can find this text and its DOI at https://tidsskrift.dk/njwls/index.

${ }^{2}$ Corresponding author: suvi.kouri@gmail.com.
} 
This paper discusses the emotional labor (Hochschild 1983) and aesthetic labor (e.g., Nickson et al. 2001) of officers in the Finnish Defence Forces (FDF) and examines the kinds of valuations they attach to the notion of an ideal soldier. The meanings the officers give to the ideals are analyzed within the wider framework of new work and compared with the traditional notion of the ideal soldier. Traditionally, the ideal soldier is considered to be physically capable and strong, rational, in control, and determinedfeatures that are culturally associated with men and masculinities (Goldstein 2001; Davis \& McKee 2004; Via 2010). According to Rones and Fasting (2017), military virtues and manhood have excluded qualities that are considered stereotypically feminine, such as emotional and physical delicacy. The existing literature often paints a picture of a professional soldier based on masculine ideals (e.g., Goldstein 2001; Haaland 2012; Jacoby 2010; Via 2010). However, the concept of masculinity does not necessarily cover all the nuances of soldiering, especially in the postmodern military, which is under constant change. Andersen (2018, p. 232) points out that the process of socialization in the military may also include 'something as "feminine" as caring'.

Finnish manhood is tightly connected with the military through male conscription (Ahlbäck 2014; Jukarainen 2012). Despite women's voluntary military service since 1995, the profession of a military officer is still highly gendered. The number of women in the FDF is $19 \%$ of all personnel (Defence Command 2019). Most of them are civilians working in the support sector (Leinonen et al. 2018). The number of women both as conscripts and as military officers is $3 \%$; of 2999 military officers, only 80 are women (Defence Command 2019). In other Nordic militaries, the percentage of female officers is higher: $11 \%$ in Norway, $9 \%$ in Sweden, and $7 \%$ in Denmark (Forsvarsministeriet 2020; Försvarsmakten 2019; Årsrapport 2018). Internationally, Nordic countries are considered forerunners in terms of gender equality (e.g., World Economic Forum 2019). However, their militaries are still heavily male dominated, and they used to be the last bastion of masculinity in Nordic working life before being opened to women. Nordic militaries are an interesting context to examine in terms of working life studies not only because of their participation in the reproduction of gender relations and segregation but also because of their potential for change.

The FDF's main task is the military defense of Finland, including training conscripts for this purpose. In addition to being a legitimized institution that uses force and even lethal violence (Godfrey \& Brevis 2018), the FDF is therefore a training institution. It has an informal societal task: raising Finnish youth to be men. Military service is traditionally considered a rite of passage from boyhood to manhood (Ahlbäck 2014). This point of view encourages scrutinizing the military officer profession as service work, in which conscripts are increasingly seen as customers. Especially at the early stage of their career, FDF officers mainly train conscripts. These activities create service-related encounters, which is typical of new work, in which conscripts are in need of emotional support from their superiors.

In this study, I examine how ideals related to new work are enacted through emotional and aesthetic labor in the traditional male-dominated military organization. The aim of this study is to identify whether there are fractures in the traditional military ideals, which could create space for feminine valuations and work to female officers' advantage. Basing on the texts and interviews of FDF officers, I analyze how they describe the ideal soldier's body, look, and emotional display. My research questions are as follows: (1) What kinds of traditional ideals and ideals related to new work are enacted through

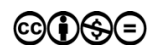


the emotional and aesthetic labor of FDF officers? (2) How do these ideals work to female officers' advantage and disadvantage?

First, this article outlines the FDF and its process of structural and cultural change, as well as the nature of military ideals. Second, it maps the concepts of aesthetic and emotional labor and how they may be utilized in studying the military. Third, the data and methods used in the study are presented. Fourth, the two results sections demonstrate how military officers perform aesthetic and emotional labor in their work. Finally, I argue that while the traditional masculine notion of the ideal soldier still exists, there are some new attributes related to new work that are coded feminine and work to female officers' advantage.

\section{Organizational change and military ideals}

Although Finland is one of the highest-ranking countries in the world when it comes to gender equality (e.g., World Economic Forum 2019), the Finnish labor market is highly segregated by gender (Reports of the Ministry of Social Affairs and Health, Finland 2008). In particular, the security sector is heavily male dominated. Male-only conscription is a major institution behind the gender imbalance in the security sector (Jukarainen 2012). According to Einiö (2019), dormmates during conscription may have long-term contributions to earnings and success in working life, mostly because of the beneficial labor market networks that are created during military service. Therefore, it may be assumed that male-only conscription affects working life in Finland both directly and indirectly and contributes to gender imbalance and hierarchies in the workplace.

Most Western militaries are restructured in similar ways and adopt the so-called postmodern model: concentrating, outsourcing, centralizing, and networking, as well as abolishing mandatory conscription (King 2006). Norheim-Martinsen (2016) argues that Europe's defense sectors have become more like other normal public (and private) sector organizations with the same dynamics and demands. Many military organizations, including the FDF, have adopted the principles of new public management (NPM), which means more transparency, accountability, and a more market-oriented approach (Leinonen et al. 2018; Norheim-Martinsen 2016). According to Norheim-Martinsen (2016), current military personnel are constantly interacting with society. In his opinion, contemporary defense organizations are increasingly influenced by public trends. Moskos, Williams, and Segal (2000) also argue that one of the characteristics of a postmodern military is the increasing permeability of the civilian and military spheres, both structurally and culturally. While other Western countries have abolished mandatory conscription, the Finnish military system remains unique, even compared with its Nordic neighbors. Both Norway and Sweden have established gender-neutral and selective conscription, whereas Denmark has selective conscription for men and voluntary service for women. Apart from maintaining male-only conscription, the Finnish military has adopted many other traits of post-modernization (Leinonen et al. 2018).

From the year 2017 onward, the FDF has had a new task defined by the lawparticipating in international support and cooperation based on the Treaty on the Functioning of the European Union and on the Treaty on European Union (Act on the Defence Forces 2017 \$2). Along with the organizational change processes described 
above, changes in warfare and the security environment have influenced the role of the FDF and the professional identity of military personnel. According to Mellström (2012), the technologization and virtualization of warfare, as well as the shift in focus from warfighting to peacemaking, have changed the very ontological meaning of what it is to be a soldier. These trends also contribute to blurring traditional gender boundaries and binaries-it makes no difference who is behind the screen when warriors become technologists. King (2013) agrees with Mellström in stating that soldiering in the postmodern military is a professional activity relying on expertise instead of an expression of manhood.

Research on gender and the military often focuses on the integration of women and the kinds of strategies female soldiers adopt to fit in to the male-dominated workplace and its masculine norms and ideals (e.g., Haaland 2012; Jacoby 2010; Persson 2011; Sasson-Levy 2003). Women who work in the military have to negotiate contradictions between cultural and organizational expectations on how femininities and masculinities are enacted. According to Steidl and Bookshire (2019), female embodiment, which is usually compartmentalized into the private sphere, is brought to the public sphere through military ideals. Women's bodies deviate from the masculine norm of the military and are therefore often represented as problematic to the organization (ibid.). Female officers are often expected to perform masculinities to be considered credible professionals (Sasson-Levy 2003).

Despite the changes in warfare, professional military identities, and conceptions of what it is to be a soldier, war is mostly a male activity both historically and cross-culturally (Goldstein 2001). According to Goldstein (ibid.), suppressing emotions, especially fear and grief, is integral to being a good warrior. Traditional ideal military masculinity is connected with the battlefield, where the display of, for instance, gentleness and compassion, is discouraged (ibid.). Agreeing with Goldstein, Davis and McKee (2004) state that the real hurdle to women's full integration in the military is the warrior framework. It over-emphasizes the soldier roles connected with war-fighting and combat operations compared with providing peace support and humanitarian and domestic support, which is practiced by the post-modern military organization. Davis and McKee (ibid.) note that military research has started to identify new skills and attributes to describe the ideal soldier. This study aims to continue identifying these new attributes and remark on the potential changes in the notion of the ideal soldier.

\section{Aesthetic labor: the right military look}

Research on service work has created two new distinct but overlapping concepts: emotional (Hochschild 1983) and aesthetic (e.g., Nickson et al. 2001) labor. They are utilized in this study as lenses through which the embodied and gendered ideal soldier is examined. Hochschild (1983) argues in her research on an airline company that the employer's control over flight attendants' physical appearance is framed as a need to be professional. Being professional also means accepting the rules of standardization. Workplace performance includes style, image, and aesthetics, and workplace success is associated with the employee's bodily discipline and appearance (McDowell 1997). Employee embodiment is an essential part of emotional labor, as it often involves facial and bodily displays (Hochschild 1983). Warhurst and Nickson (2009) argue that the 
paradigm of emotional labor needs to be extended to aesthetic labor, which foregrounds embodiment and reveals how, in addition to feeling, employees' corporeality is appropriated to an organization's commercial benefit. When emotional and aesthetic labor are used in a service encounter, the aim is to affect a certain state of mind in the customer (Hochschild 1983; McDowell 2009; Nickson et al. 2001). In the military context, this translates to producing a sense of security for fellow citizens (Godfrey \& Brevis 2018).

Aesthetic labor includes giving a good, tidy, and pleasant impression. It is not merely relevant in a singular customer encounter, but the image of the organization is also created through it (Heiskanen et al. 2008). When doing aesthetic work, the employee modifies their body to meet the demands of the organization. The right look, a certain kind of embodied performance, is desired from the employee to fit the image of the organization, including, for instance, the ideal size and voice (Nickson et al. 2001). The female body is usually seen as weaker, smaller, and less authoritative (Cockburn 1991). Emotionality and weaker physical performance, which are linked to women, have often been used as arguments to hinder women from entering the military profession. In the military and in other fields in the security sector, physical appearance and performance are seen as central for doing the job (e.g., Bloksgaard et al. 2020).

The right military look is regulated by the official doctrine (Halonen \& Karvinen 2017). The military has always used the soldier's body as a medium. The body has been molded through organizational rules, restrictions, and requirements. The ideal military body also expresses the mental character of the employee: good self-discipline, never being tired, and always being in control (Sasson-Levy 2008). According to the law, soldiers need to be in good physical shape: 'Professional soldiers are required to maintain the basic military skills and physical condition commensurate with their duties' (Act on the Defence Forces, $\mathbb{\$} 43$ ). All professional soldiers working in the FDF are obliged to carry out yearly fitness tests (Vaara et al. 2016).

Soldiers' bodies also face pressure related to cultural representations. According to Rones and Fasting (2017), the cultural script of militarism offers soldiers the possibility to be identified with the ideal of the chosen body. The historical Finnish national imagery of the military is based on World War II, when the typical soldier was a thin reservist, looking a bit suffered, with poor equipment and clothing, fighting in the deep forest (Jokinen 2019). This imagery still lives on in the military but has partially been replaced by international representations. The modern imagery is mostly based on the American film industry - the muscular and robust special forces warrior, with the latest and most technical equipment, fighting in Afghanistan or some other remote war zone (Rones \& Fasting 2017).

\section{Emotional labor in the military}

In addition to personal look, emotions are used as instruments at work. In the context of new work, employees' emotions and other soft skills are at the disposal of the employer (McDowell 2009). Social competence and emotional intelligence are needed in today's working life, in which interacting with people has become more and more central (Kelan 2008a). However, emotions are strictly controlled and managed in the work context. Expressing unaccepted emotions and losing control at work are considered unprofessional behavior and a sign of weakness (Hochschild 1983). International research on 
emotional labor in the military has mainly focused on combat operations (Godfrey \& Brewis 2018) and other crisis situations (Alvinius et al. 2015) or a peace enforcement context (Alvinius et al. 2014).

Men and women meet with different kinds of expectations and stereotypes in terms of emotional labor. Negative emotions, such as anger and other forms of aggression, are usually gendered as masculine, whereas positive emotions, such as empathy and caring, are positioned as feminine demeanor (Godfrey \& Brevis 2018; Hochschild 1983). Women are typically expected to be more emotional than men and are therefore frequently portrayed as mentally weaker. According to Hochschild (1983), women are expected to master anger and aggression and to be nice, whereas men can use anger as a resource in their work. When emotional labor is performed in a public space, men are usually seen as representatives of authority and command, whereas women represent caring wives and mothers or independent career women (Heiskanen et al. 2008; Hochschild 1983).

Emotional labor includes organizational restrictions and acknowledging the lower valuation of some emotions. Hochschild (1983) calls these organizational norms feeling rules. In addition to positive or negative emotions, feeling rules may require the absence of emotion in certain situations. According to Godfrey and Brevis (2018), recruits entering the military learn organizational feeling rules through the process of socialization. The nature of the military as an institution of legitimized violence creates an exceptional context for emotional labor. Unlike in most service occupations, the feeling rules in the military require performing negative emotions along with positive emotions (ibid.).

Female leaders usually need to fight stereotypical expectations and prejudices, such as women lacking the toughness and competitiveness needed to succeed (Eagly 2007). In masculine environments, such as the military, women are balancing on a tightrope, facing both the cultural expectations of femininity and the organizational expectations of masculinity (ibid.). Female officers typically have to work with or against gender stereotypes when meeting the expectations of their colleagues and trainees. According to Hochschild (1983) and McDowell (1997), manipulating bodily images and emotions for the use of the employer may alienate employees from their feelings. McDowell (1997, p. 201) describes how female informants talked about 'building up a shell' or 'not using my [their] real personality'.

\section{Data and methods}

This study is based on 108 FDF officers' texts and 12 interviews on the theme of the ideal soldier. The group of informants consists of officers who have around 10-15 years of work experience. The age range of the officers is from early 30s to early 40s. At the time of gathering the data, the informants were attending a career course, which defines the high positions they can reach during their career. Some of them have completed the two-year-long General Staff Officer Course, which enables them to reach the highest positions at the FDF. Others have completed the five-month-long Senior Staff Officer Course, which means that the highest positions are out of their reach. Therefore, the career course is an important turning point in an officer's career and the choices they make, essentially forcing them to reflect on their past and future in terms of their work and private lives. I selected the group of informants based on the mutual similarity of 
their situation and their position and long experience as military officers. This created the opportunity to compare the conceptions of individuals instead of certain groups, as well as to understand some possible changes that the officers had experienced during their career.

I applied for a research permit from the Defence Command to gather data for my research, and I visited the above-mentioned classes. Some students were absent, but I was able to reach the majority of the course participants, who were around 80 students per course. Participating in the research was voluntary. The officers were given 30 minutes to write about their conceptions of the ideal soldier, how they perceive themselves in relation to the ideal, and how their career and other aspects of their lives have influenced their conceptions. The length of the text was not limited. I received 108 texts, which meant that approximately $70 \%$ of the course students volunteered to participate in the study. From the 108 writings, women wrote eight because there were only a few women in both courses. Most of the texts were from half a page to one page long. Some of them consisted of only a few sentences or a short list of preferred qualities for the ideal soldier.

I interviewed eight male and four female officers. As the notion of the ideal soldier appeared so explicitly gendered in the writings, the women are overrepresented among the interviewees. I selected the interviewees based on their texts and their expressed willingness to participate. I also wanted them to represent the whole range of different kinds of conceptions presented in the texts. The interviewees were asked questions about the ideal soldier, military career, professional identity, and the themes that arose from their writings. I recorded and transcribed the interviews. The duration of the interviews varied from 45 minutes to a little more than 2 hours. The quotes in the analysis are marked with 'W' (writing) and 'I' (interview). All quotes are my own translations from Finnish. I marked only the gender of the informant under the quotes because it is the most relevant factor in the analysis. All other identifiers are left out to protect the anonymity of the informants, especially the female officers, because there are so few of them. Moreover, I had to leave out some information that could have been useful for the research because they were so personal and specific that they could be traced to the person who said it. For the same reason, I chose not to specify participant profiles but to handle them as a group. Any details of the participants' age, family, or other identifiers would endanger their anonymity.

It can be assumed that a person's age, work experience, position in the military hierarchy, and key experiences in their personal life affect their conceptions and valuations concerning the ideal worker. I did not define the concept of the ideal soldier when giving the writing task to the students. I asked them to define their own conception. By using texts and asking the respondents to create their own definitions, my aim was to participate less in the process of knowledge production in comparison to the interviews. Some respondents wanted to specify that they were actually writing about the ideal officer, which differed from other soldiers, such as conscripts, non-commissioned officers, and so forth. All participants were at the stage in their career in which most of their work consisted of days at the office in front of a computer. Most of them had experience in training conscripts but were not doing it anymore. The participants' position at the time of the data gathering has most likely played a part when they defined their conception of the ideal soldier.

I used theory-conducted content analysis to find the meanings in the texts and the meanings that the respondents produced in interaction with the interviewer (Tuomi $\&$ 
Sarajärvi 2009). After reading the texts several times thoroughly, I started to notice some recurring themes related to the framework of new work. Based on those themes, I chose some code words and coded the writings and transcriptions of the interviews accordingly. After coding, I perceived that the informants could be divided very roughly into two categories: those who represent the traditional notion of the ideal soldier and those who have adopted some qualities and attributes from the framework of new work in their conception of the ideal soldier. In theory-conducted analysis, the abductive approach enables dialogue between the data and theories throughout the research process (Tuomi \& Sarajärvi 2009). To move away from descriptive analysis into the deeper level of meanings, I then reread the data and categorized and analyzed them according to the theoretical understanding of aesthetic and emotional labor performed by the officers (Gibbs 2007). In the following sections, I present my findings on the kinds of ideals the FDF officers enact through aesthetic and emotional labor and how their conceptions of the ideal soldier work to female officers' advantage and disadvantage.

\section{Findings}

\section{The ideal military body}

In most of the officers' texts, the feature of being physically capable was attached selfevidently to the ideal soldier. At first glance, the physical requirements of the ideal soldier may seem obvious based on the legal duties and tasks of military personnel and the nature of war. However, the officers gave varied meanings to being physically capable. According to my analysis, good physical fitness was given meanings related to both traditional military ideals and the framework of new work and aesthetic labor. It was not only about being able to complete certain physical tasks but also about the image of the organization, of having the right look.

\section{Battlefield ideals}

The traditional notion of the ideal soldier emphasizes the significance of being in good shape based on the bodily nature of war-related tasks. It includes historical elements and refers to the military profession as an ancient task performed only by men:

The conception of the ideal soldier (in my opinion) is based on a quite old, partially romantic picture: the soldier (officer) leads his troops in the field from the frontline and attacks with his bayonet upright, while his troops follow toward the final and eternal victory. The soldier dedicates his life in a manly and gratuitous way to national defense and the fatherland, for which he is ready to give the greatest sacrifice-his own life. (male officer, W)

The ideals related to the military core-combat—are explicitly gendered, and they hardly leave any room for female soldiers (also Persson 2011). To fit the ideal, female soldiers are typically expected to perform masculinities (Sasson-Levy 2003). When the body of the soldier does not meet standards and requirements, it becomes highly visible and an 
object of evaluation and judgment: whether it be an older body, an overweight body, a disabled, too small, or too weak body, a female body, or even a pregnant body. One of the female informants discussed another female colleague who had been pregnant while working and training conscripts.

The conscripts just stared when she took her jacket off, just stared with their mouths open. She said that it was such a total showstopper. Like, how is this possible, how should one act and react? Like, hey, it's nothing, just rush forward as usual, nothing changes, yes, it's a baby belly. (female officer, I)

The pregnancy in a way revealed the female body. Gatrell (2011) argues that pregnancy makes women highly visible in the workplace and shows their leaky, vulnerable and unpredictable body. The ideals emphasizing war and the ability to fight were in strong contrast to (1) a female body about to give birth to a new life and (2) becoming a caring mother, which is related to the traditional dichotomy of soldier/mother. On the other hand, a pregnant military professional may also participate in deconstructing the dichotomy by presenting a novel representation of a soldier.

\section{Inferior female bodies}

Only one of the female informants did not mention gender at all in her writing, which consisted of only five sentences. However, out of the eight women, seven reported in their writings that gender is a relevant factor when it comes to reaching the ideal and the demands of the military profession. One of the seven described her conception as follows:

I am a female officer. I consider the ideal officer to be a male. The ideal male officer is physically in good shape, capable of independent action and decision making. His psyche is strong, and his ability to lead troops comes as natural. The image of a 'rough soldier' is still strong even in my own mind. (female officer, W)

Most of the female officers expressed in their texts and interviews that they felt inadequate as soldiers, as their physical performance is not at the same level as that of their male colleagues. The physical differences between men and women have traditionally been used as an argument to exclude women from the military. The shortcomings in physical performance may be compensated for by working harder and performing more emotional labor. Emotional labor is elaborated in the following section. Although the officers' daily work in most cases does not include demanding, let alone insurmountable, physical tasks, the women seem to feel inferior because of their female bodies (also McDowell 1997). One of them described the feeling after yearly fitness tests as follows:

I mean it's such an oppressive mental factor, which one encounters every year, and it causes such a feeling of inferiority that I'm just so bad at this. (female officer, I)

However, the same woman said that she had run several marathons and half marathons, and based on that, she expressed that she refuses to believe she is out of shape. The fitness tests, although often described as gender neutral, may, in fact, be biased toward 
male capabilities and therefore reproduce gendered ideals. Some male informants found it important for the tests and physical standards to be the same regardless of gender. They saw all kinds of exceptions of the task-related demands as positive discrimination, which they found explicitly wrong.

Traditional ideals do not treat men and women equally. There still are no female officers at the top of the hierarchy in the FDF. The lack of role models leaves the women with no one to truly identify with. One of the women described the situation by referring to the patriarchal culture, which has been perpetuated for thousands of years.

\section{The right military look}

Cultural representations are important in constructing the ideal soldier. They work to women's disadvantage because women's bodies mark their difference from the organizational and cultural norms of a soldier. The traditional image of the Finnish warrior in the deep forest leaves no space for women-nor does the modern image of the muscular special force warrior.

But it's the image that we have, from television, based on movies and such, how a soldier should look like, how they should be. (female officer, I)

According to Coleman (2008), people not only emulate media images but experience their own body through media images. When experiencing their own body through cultural representations, women feel inferior as soldiers. One of the male informants pointed out quite explicitly the factors that he sees as essential to the ideal. In addition to weight, he expressed gender and age as relevant factors when talking about a credible soldier-someone who 'look[s] like a soldier'. For him, women, overweight, and older soldiers are one step behind before they can be considered good soldiers.

I do feel that a soldier has to be at an adequate level when it comes to their physical qualities. A soldier should look like a soldier. For example, overweight soldiers will have a hard time convincing me [of their professionalism], even if their knowledge is at a good level. (male officer, W)

The informant gave certain meanings to the right military look-receiving societal appreciation and looking like someone who can complete the task appointed to them. The meanings given to the embodied attributes of the ideal soldier are connected with aesthetic labor. The embodiment of the soldier does not only include the capability to run fast, to carry heavy equipment, or to be able to fight. Many of the informants viewed the bodily ideals from the perspective of the aesthetic labor performed by the soldier, instead of labelling it only as the capability to fight.

My conception of the ideal soldier is a soldier who is confident while performing. Their appearance is sporty and muscular. They are in good shape, and their basic skills as soldiers, such as shooting, are at an excellent level. They use elaborate language and do not swear. - One is able to trust the ideal soldier, and their behavior is very predictable. Such behavior creates a sense of security. (male officer, W) 
The right military look has to do with the relationship between the military and society, as well. A soldier's task is to produce a sense of security for society, the country, and its citizens (Godfrey \& Brewis 2018; Norheim-Martinsen 2016). The ideal military body presents soldiers as trustworthy and capable of protecting the nation and civilians. Officers are required to perform aesthetic labor, and their bodies represent the image of the military organization (Warhurst \& Nickson 2009). When I asked the interviewees about the kinds of meanings they give to the ideal body, they stated attributes, such as being secure, trustworthy, credible, confident, qualified, healthy, and vibrant. In essence, how the soldier looks is also part of a larger embodied performance, which includes a tidy and well-fitting uniform, shiny combat boots, short hair and shaved face for men, and good manners and polite behavior.

Although the right military look is regulated by the organization, many informants also attached embodied attributes to their personal view of the ideal soldier. When institutional regulations are well internalized, they become part of the employees' personal views. Although many subscribed to the idea of a certain look expressing certain attributes, this view was not unanimously shared. Instead, many of the informants criticized strict regulations concerning the right military look and the close connection with the ideal soldier. Some of them said that physical appearance was only a superficial display; it does not reflect who a person really is and how they do their job. This kind of criticism is a sign of fractures in the traditional ideals, as the emphasis is on utilizing the whole personality of the employee or 'being oneself,' as many of the informants mentioned (also Parviainen 2016).

\section{Feeling rules of the military}

Examining the emotional labor of military officers connects the profession tightly with the ideals of new work. It draws attention from war-related tasks to peacetime training and service-related encounters. In addition to the look of the employee, emotions are also at the disposal of the organization.

\section{'You can't be sensitive'}

The traditional ideals include the machine-like, callous soldier with restricted emotional expressions defined by the feeling rules of the organization (Hochschild 1983). These ideals are associated with combat situations, in which one has to be able to continue fighting even if a close person dies right next to them.

I feel that there's maybe this: a soldier shouldn't express emotions. That you should be, in a certain way, cold and callous. It's like when there's combat, well, a fellow died next to you, but let's just continue. - I think it might be that you can't be sensitive because when you express emotions, we think that when the first one is wounded and dies, you'll break down. (female officer, I)

A female informant described a peacetime situation in which a fellow officer died. She was advised by her colleagues not to express grief because they considered it inappropriate 
for a soldier. Although most of Finnish officers' work takes place in a peacetime environment, they seem to be expected to perform emotional labor as if they were, in fact, at war. The closest they get to a war-like situation would be as part of international operations. However, serving abroad is voluntary for FDF officers, and the number of officer positions in operations is limited, so not all of them get this experience (Defence Command 2019).

The expectation for performing emotional labor related to war-like situations includes strict feeling rules concerning the kinds of emotion expressions that are allowed. Two female informants mentioned explicitly in the interviews that they have had to 'build up a shell' to perform as the ideal soldier (also McDowell 1997). They reported that they hide certain emotions, such as sorrow, which is often interpreted as an expression of weakness in the military context and could later be used against them. What the female officers reported shows that the female body is still labelled as emotional and weak.

— and then something like 'women can't kill anyone.' Um, can't they? Or something like 'you're such sensitive mother figures' and so on. (female officer, I)

The traditional ideals related to war leave very little room for the expression of emotions stereotypically connected with weakness. The ultimate task for a soldier is to take the life of another person on the battlefield. Women are seen, as the previous quote shows, as 'sensitive mother figures' incapable of killing anyone. Stereotypically, men are considered more able and ready for extreme forms of aggression, such as killing enemies in combat situations. The stereotype of women as nurturing mothers is working against them in this type of military context. However, the expression of emotions seems to be allowed for those men who otherwise reach military ideals. One of the male officers described his experience as follows:

- there is this certain kind of communality that if I have felt down or anxious or something like that, I don't need to... there's no doubt that I wouldn't be supported. No, men and women will surround me offering their help. (male officer, I)

The male officer's quote is an interesting contradiction to the female officers' experiences. He was obviously not afraid of people using the situation against him. While the women felt they must hide their 'weakness' and must not express certain types of emotions, the male officer said that he can always count on his colleagues to offer help and support. For this man, who is considered closer to the image of an ideal soldier, it was easier to express sorrow. There seems to be different feeling rules depending on one's gender. According to Fineman (2000), issues of power imbalance and hierarchy seem to play a part in people's willingness to reveal their pain in the workplace.

\section{Lack of authority}

One of the male informants expressed that positive emotional labor comes naturally for him, but he finds himself struggling with the need to display negative emotions needed in superior work.

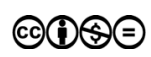


For me, maintaining objectivity and understanding people as individuals is the easiest. I usually succeed in creating quite a good team spirit in the group I'm leading, but as a downside, it's more difficult for me to be 'hard' enough to my subordinates when problematic cases would require it. I'm capable of it, but I don't like it. (male officer, W)

This contradicts the traditional stereotypes of men. Pondering their relation to the features of the ideal soldier, many of the informants reported being socially competent. They saw their skills as something natural and used that side of their personality as a resource at work. Emphasizing social interaction and the use of soft skills (McDowell 2009) in the military officer profession can be interpreted as emotional labor related to service work, in which features culturally coded as feminine are also appreciated.

When the men described themselves, they did not express these features to be gendered, but they attached these to their personalities. Nevertheless, many of the informants, both men and women, considered women to have better social skills-a typical cultural stereotype connected with female leaders, as Kelan's (2008b) study points out. When I asked the interviewees whether the entry of women into the military caused any changes in Finnish military culture, they reported positive changes in interaction within the military community. In contradiction to the previous statement, the women reported having received bad evaluations from their peers during their career course when it came to interaction skills. A reason for this contradiction might be that one factor evaluated is authority.

Most had listed authority as something I need to improve, and I was like, I have worked (number of years) as a chief in a conscript unit; I've never had any problems with my authority. On the contrary, when I was relocated from (unit) to (unit), there was a rumor going around among the conscripts that I was relocated there because I'm the only chief who's able to restrain these (branch of service) men. (female officer, I)

This woman's description indicates that her course peers, who had not seen her at work, assumed that she had difficulties with asserting her authority. Yet again, the stereotypes work to the women's disadvantage (Hochschild 1983). The informant was not expected to be able to display negative emotions, which were considered necessary to restrain the conscripts. She said that her colleagues, who work with her daily, ask for her help in situations in which there is a special need to be strict. She talked about these features as gender neutral and said that it is instinctual for her to be harsh when needed. Although she saw it as natural for her, she pointed out that men do not see it as gender neutral but instead as masculine demeanor.

Some female informants mentioned in the interviews that they had discussed the course peer evaluations with other women and found that almost all of them were at the bottom of the list. One of them compared their time at the career course with their time at the cadet school. There is the same competitive situation, and the students are striving for the best placements in their future careers.

- we fight for the placements on this course, and some of us think, like the career-oriented ones, that peer evaluation is a good place to pull women down in order to foster one's own success. (female officer, I) 
This context shows that traditional ideals still exist quite strongly. Along with the competitive situation, stereotypical thinking, according to which women lack competitiveness, toughness, and authority, leads to the male course peers giving bad evaluations to the women (also Eagly 2007).

\section{'Treating them as human beings'}

One of the male informants reflected on an officer's leadership skills regarding working as a superior for experts and specialists, who are mostly civilians.

And to recognize and nourish individuality requires really strong emotional intelligence, which is very rarely taken into account in our recruiting processes. - And this is one of the reasons, although quite stereotypically, why I'd be more than happy to see more female officers as leaders. (male officer, I)

He pointed out that women are stereotypically considered to have more ability in the field of emotional intelligence. This appreciation of emotional intelligence may work to female officers' advantage. The following quote underlines the need for compassion as a leadership tool. One of the female officers described how she gained respect and acceptance from her subordinates.

- you need also, you know, that compassionate side, especially there, well, I use again the conscript company as an example, that if someone really has a problem and they need a kind of a mother figure, then you just have to bring that side; I claim that women are better, well, not all of us - you read from the feedback, that you've gained respect with that. That you've dealt with the situation and treated the person as a human being - (female officer, I)

The informant mentioned that both conscripts and civilian experts gave excellent feedback on her leadership skills. This differed totally from the evaluations of her course peers. The previous ones were based on experiences and the latter on assumptions and stereotypes, which are apparently gendered ones. Utilizing gender differences as a resource does not work equally for all. Women most likely do not receive any special benefit for their feminine demeanor because according to gender stereotypes, women are naturally caring and compassionate. When the course participants were evaluated by their peers, the women were not rewarded for their compassion, emotional intelligence, or social skills.

One thing I've also thought about a lot is that I've had to work extra hard as a leader, a person, and a soldier - I talked with one of the men, that he has naturally good authority and such, he said that he didn't have to go through these things at all. And I've gone through really painful things about myself to become a better soldier and a better military leader. - I was even a bit envious. I wish I could be naturally as good; I've had to work so hard to become good. (female officer, I)

The female informant described how those who do not reach the demands of the ideal naturally have to adopt certain skills in order to compensate for their flaws (also 
Hochschild 1983). Most of the women reported the need to work as many times harder than the men do in order to be considered professionals. Women, who are lacking other resources in their working life because of gender, draw on emotional capital as a resource (also Hochschild 1983). The female officer supposed that women may have a broader range of leadership tools, such as emotional intelligence and the ability to lead diverse groups of people. As they lack some qualities, such as authority, which men are assumed to have naturally, they have had to develop other skills and qualities. The female informant did not see soft skills as something natural for women but as skills that can be learned, and these are valued highly (also Kelan 2008b).

When acting according to the image of the new officer, I am praised by my male colleagues, and they express approval of me. - Rough men are more and more replaced by intelligent leaders, who have emotional intelligence, as well. Even war has changed. Warfare doesn't need the traditional officer but a leader who has a wide and deep understanding of the world and of technology. (female officer, W)

Many of the informants expressed that they have seen changes in the Finnish military culture, especially in military leadership. They list new work-related feminine valuations and ideals, such as emotional intelligence and social competence, and see these as positive updates in the traditionally masculine military community and profession. The quote above indicates that changes in warfare, working life, and leadership culture are creating more space for military officers-regardless of gender-to practice their profession in diverse ways according to their own personality.

\section{Conclusion}

The purpose of my study was to examine how ideals related to new work are enacted in the FDF through the emotional and aesthetic labor performed by military officers. To answer my research questions, I gathered data consisting of 108 texts and 12 interviews concerning officers' conception of the ideal soldier. Although the majority of the respondents were men, I chose to focus on women in this study. However, including men in the data enabled me to grasp femininities and masculinities performed by military officers regardless of their gender. On one hand, through the gendered and embodied nature of aesthetic and emotional labor, I was able to identify the factors that hinder female officers from reaching the demands of the ideal soldier. On the other hand, observing these forms of labor revealed fractures in the traditional ideals and indicated new ways of practicing the military officer profession.

The present study contributes to the literature by expanding the understanding of how emotional and aesthetic labor are performed in a traditional organization, such as the military. Because of the nature of military activities, armed forces are usually seen as fundamentally different from other organizations (Norheim-Martinsen 2016). However, the FDF has adopted some traits from NPM, and it is increasingly interacting with society. Therefore, I argue that feminine valuations of new work are becoming part of military ideals. The new ideal soldier is expected to perform bodily and emotional displays, which are typically considered feminine and are usually performed by women in service work. The FDF offers an interesting context 
for examining military officers' emotional labor in service-related encounters with conscripts.

In the examination of the aesthetic and emotional labor of military officers, it became obvious that its embodied nature is the biggest obstacle in degendering the soldier. According to Sasson-Levy (2008, p. 306), the body of the ideal (combat) soldier only exists in relation to the 'wrong military body.' Steidl and Brookshire (2019, p. 1272) argue in their study that 'symbolic embodiment' threatens women's inclusion in the US military, and female bodies are seen as 'physically weak, as leaky/unclean and as sexually distracting'. Consistent with previous research, I state that despite the ideals transitioning from the traditional masculine ones to those related to new work and aesthetic labor, the ideal military body is still masculine. However, whether the existing ideals regarding soldiers' physique meet the demands of today can be questioned, as warfare is becoming increasingly technologized, and there is more need for intellectually capable soldiers with vast competence and for experts in very specific fields (King 2013; Mellström 2012).

When emotional labor is understood as an expression of compassion, sympathy, and support, it seems to be welcomed in the military regardless of gender. Nevertheless, the expression of other more personal emotions, such as grief, is still seen as a sign of weakness, especially for women. For men who reach the norms and ideals of the military, expressing so-called soft emotions is allowed, whereas women feel a greater need to manage their emotions. Stereotypes of women as emotional, compassionate, and nurturing lead to the assumption that women lack the authority needed in the hierarchical military organization and the toughness required in combat situations. According to my findings, the core business of the military-war-is still loaded with masculine ideals and valuations.

However, my study shows that female officers are usually assumed to have better social skills, emotional intelligence, and the capacity for compassion when their subordinates need support. Although soft skills may be considered personal qualities regardless of gender or can also be learned by men, women reported gaining appreciation by practicing emotional labor. Many of the men also welcomed more women in the military and expressed their respect for female officers, who, in their opinion, often had a broader range of leadership tools, such as emotional intelligence and the ability to lead diverse groups of people. This is also in accordance with the stereotypes connected with female leaders in other fields (Kelan 2008b).

Despite the officers' similar educational background, number of years of service, and wage and position in the organizational hierarchy, gender stereotypes create an illusion of a gendered division of labor and leave women in a less advanced position. However, my findings suggest that despite the stereotypes working against women, there are some feminine attributes included in the new military ideals that may work to female officers' advantage in their everyday work practices, leadership, and customer encounters. Overall, although my findings show that the traditional masculine notion of the ideal soldier still exists in the FDF, new attributes related to new work can also be identified. Some of these attributes are coded as masculine, but creating space for redefinitions of the notion of the ideal soldier and welcoming feminine valuations may slowly work for the better inclusion of female officers.

Finland is one of the most gender-equal countries in the world (World Economic Forum 2019) and, with male-only conscription, offers quite an exceptional context 
for examining gender in the military. However, this uniqueness also results in certain research limitations, so the findings of this study cannot be generalized. The limited data, which involve only few women, must be acknowledged. The study's strengths include its novel perspective in examining the changes in military ideals and its rich qualitative data. As such, this study contributes to a deeper understanding of how gendered norms and ideals could be challenged to allow for a broader variety of ways to be a military professional. For future research, it would be particularly interesting to examine and compare how military professionals from different levels of the military hierarchy perceive the notion of the ideal soldier.

\section{References}

Adkins, L. (2002). Revisions: Gender and Sexuality in Late Modernity, Buckingham: Open University Press.

Adkins, L., \& Jokinen, E. (2008). Introduction: gender, living and labour in the fourth shift, NORA-Nordic Journal of Feminist and Gender Research 16(3): 138-149. https://doi. org/10.1080/08038740802300947.

Ahlbäck, A. (2014). Manhood and the Making of the Military. Conscription, Military Service and Masculinity in Finland, 1917-39, Surrey: Ashgate Publishing Limited.

Alvinius, A., Elfgren Boström, M., \& Larsson, G. (2015). Leaders as emotional managers: emotion management in response organisations during a hostage taking in a Swedish prison, Leadership \& Organization Journal 36(6): 697-711. https://oi.org/10.1108/ lodj-11-2013-0142.

Alvinius, A., Kylin, C., Starrin, B., \& Larsson, G. (2014). Emotional smoothness and confidence building: boundary spanners in a civil-military collaboration context, International Journal of Work Organisation and Emotion 6(3): 223-239. https://doi.org/10.1504/ ijwoe.2014.065757.

Årsrapport. (2018). Forsvarets Årsrapport [Defence Forces Annual Report]. https://www. nsd.no/polsys/data/filer/aarsmeldinger/AN 2018 56989.pdf.

Bloksgaard, L., Fekjaer, S. B., \& Moberg, R. J. (2020). Conceptions of gender and competencies among police recruits in Scandinavia, Nordic Journal of Working Life Studies 10(2): 43-59. https://doi.org/10.18291/njwls.v10i2.120818.

Castells, M. (1996). The Information Age: Economy, Society and Culture. Vol I: The Rise of the Network Society, Oxford: Blackwell.

Cockburn, C. (1991). In the Way of Women: Men's Resistance to Sex Equality in Organizations, Basingstoke: Macmillan.

Coleman, R. (2008). The becoming of bodies: girls, media effects, and body image, Feminist Media Studies 8(2): 163-179. https://doi.org/10.1080/14680770801980547.

Davis, K. D., \& McKee, B. (2004). Women in the Military: Facing the Warrior Framework. In F. C. Pinch, A. T. MacIntyre, P. Browne, \& A. C. Okros (Eds.) Change in the Military: Gender and Diversity Issues. (pp. 52-75), Winnipeg: The Wing Publishing Office.

Defence Command. (2019). Henkilöstötilinpäätös [Annual Report on Personnel], Helsinki: Pääesikunta.https://puolustusvoimat.fi/documents/1948673/2267037/PEVIESTOS henkil \% C3\% B6st \% C3\%B6tilinp \% C3\% A4\%C3\%A4t\% C3\% B6s 2019.pdf/0f1f588d-3 e06-585f-4228-f8522fa8ac52/PEVIESTOS henkil \% C3\%B6st \% C3\% B6tilinp \% C3\% A4\%C3\% A4t\%C3\%B6s 2019.pdf.

Eagly, A. H. (2007). Female leadership advantage and disadvantage: resolving the contradictions, Psychology of Women Quarterly 31(1): 1-12. https://doi.org/10.1111\%2Fj. 1471-6402.2007.00326.x. 
Einiö, E. (2019). Mixing the Rich and Poor: The Impact of Peers on Education and Earnings, Helsinki: VATT Working Papers 128. https://oi.org/10.2139/ssrn.3511966.

Försvarsmakten. (2019). Personalsiffror [Personnel Figures]. https://www.forsvarsmakten.se/ sv/organisation/om-var-organisation/personalsiffror/.

Forsvarsministeriet. (2020). Kvinder i Forsvaret (Women in Defence Forces]. https://forpers. $\mathrm{dk} / \mathrm{da} / \mathrm{hr}-\mathrm{i}$-tal/kvinder/.

Gatrell, C. (2011). Policy and the pregnant body at work: strategies of secrecy, silence and supra-performance, Gender, Work and Organization 18(2): 158-181. https://doi. org/10.1111/j.1468-0432.2009.00485.x.

Gibbs, G. R. (2007). Analyzing Qualitative Data, London: Sage Publications.

Gibson-Graham, J. K. (1996). The End of Capitalism (As We Knew It). A Feminist Critique of Political Economy, Cambridge, Mass.: Blackwell.

Godfrey, R., \& Brevis, J. (2018). 'Nowhere else sells bliss like this': exploring the emotional labour of soldiers at war, Gender, Work and Organization 25(6): 653-669. https://doi. org/10.1111/gwao.12229.

Goldstein, J. S. (2001). War and Gender. How Gender Shapes the War System and Vice Versa, Cambridge: University Press.

Haaland, T. L. (2012). Friendly War-Fighters and Invisible Women. Perceptions of Gender and Masculinities in the Norwegian Armed Forces on Missions Abroad. In A. Kronsell \& E. Svedberg (Eds.) Making Gender, Making War. Violence, Military and Peacekeeping Practices. (pp. 63-75), New York: Routledge.

Halonen, P., \& Karvinen, I. (Eds.) (2017). Yleinen palvelusohjesääntö [General Service Regulation], Helsinki: Pääesikunta. https://puolustusvoimat.fi/documents/1948673/2258487/ PEVIESTOS YLPALVO+2017/3684dac2-c7ac-4d93-b792-34649f6e2f5d/PEVIESTOS YLPALVO+2017.pdf.

Heiskanen, T., Korvajärvi, P., \& Rantalaiho, L. (2008). Sukupuoli ja työ: pysyvyyttä ja liikahduksia [Gender and Work: Stability and Mobility]. In T. Heiskanen, M. Leinonen, A. Järvensivu, \& S. Aho (Eds.) Kohti uutta työelämää. Tutkimuksen näköala työelämän kehitykseen [Towards New Working Life. The Research Perspective on Development of Working Life]. (pp. 109-134), Tampere: Tampere University Press. http://urn.fi/URN: ISBN:978-951-44-7630-3.

Hochschild, A. R. (1983). The Managed Heart. Commercialization of Human Feeling, Berkeley \& Los Angeles: University of California Press.

Jacoby, T. A. (2010). Fighting in the Feminine: The Dilemmas of Combat Women in Israel. In L. Sjoberg \& S. Via (Eds.) Gender, War and Militarism. Feminist Perspectives. (pp. 80-90), Santa Barbara, California: Praeger Security International.

Jokinen, A. (Author); Soikkeli, M., \& Kivimäki, V. (Eds.) (2019). Isänmaan miehet - Maskuliinisuus, kansakunta ja väkivalta suomalaisessa sotakirjallisuudessa [The Men of the Fatherland - Masculinity, Nation and Violence in the Finnish War Literature], Tampere: Vastapaino.

Jukarainen, P. (2012). Men Making Peace in the Name of Just War. The Case of Finland. In A. Kronsell \& E. Svedberg (Eds.) Making Gender, Making War. Violence, Military and Peacekeeping Practices. (pp. 90-103), New York: Routledge.

Kelan, E. K. (2008a). Emotions in a rational profession: the gendering of skills in ICT work, Gender, Work and Organization 15(1): 49-70. https://doi.org/10.1111/j.14680432.2007.00355.x.

Kelan, E. K. (2008b). The discursive construction of gender in contemporary management literature, Journal of Business Ethics 81(2): 49-70. https://doi.org/10.1007/s10551-0079505-2.

King, A. (2006). The post-Fordist military, Journal of Political and Military Sociology 34(2): 359-374. https://search.proquest.com/docview/206650624? accountid=11774. 
King, A. (2013). The Combat Soldier: Infantry Tactics and Cohesion in the Twentieth and Twenty-first Centuries, Oxford: Oxford University Press.

Leinonen, M., Nikkanen, R., \& Otonkorpi-Lehtoranta, K. (2018). Organizational change and employee concerns in the Finnish Defence Forces, Nordic Journal of Working Life Studies 8(3): 135-153. https://doi.org/10.18291/njwls.v8i3.109544.

Lewis, P., \& Simpson, R. (Eds.) (2007). Gendering Emotions in Organizations, Basingstoke: Palgrave Macmillan.

McDowell, L. (1997). Capital Culture: Gender at Work in the City, Oxford: Blackwell.

McDowell, L. (2009). Working Bodies: Interactive Service Employment and Workplace Identities, Chichester: Wiley-Blackwell.

McNay, L. (1999). Gender, habitus and the field: Pierre Bourdieu and the limits of reflexivity, Theory, Culture and Society 16(1): 95-117. https://doi.org/10.1177\%2F0263276990 16001007.

Mellström, U. (2012). Changing affective economies of masculine machineries and military masculinities? From Ernst Jünger to Shannen Rossmiller, Masculinities and Social Change 2(1): 1-19. http://dx.doi.org/10.4471/MCS.2013.19.

Ministry of Social Affairs and Health, Finland. (2008). Segregation and the Gender Wage Gap, Helsinki: Ministry of Social Affairs and Health.

Moskos, C. C., Williams, J. A., \& Segal, D. R. (2000). The Postmodern Military. Armed Forces after the Cold War, Oxford: Oxford University Press.

Nickson, D., Warhurst, C., Witz, A., \& Cullen, A. M. (2001). The Importance of Being Aesthetic: Work, Employment and Service Organization. In A. Sturdy, I. Grugulis, \& H. Willmott (Eds.) Customer Service. Empowerment and Entrapment. (pp. 170-190), Basingstoke: Palgrave.

Norheim-Martinsen, P. M. (2016). New sources of military change - armed forces as normal organizations, Defence Studies 16(3): 312-326. https://doi.org/10.1080/14702436.2016. 1195234.

Parviainen, J., Kinnunen, T., \& Kortelainen, I. (Eds.) (2016). Ruumiillisuus ja työelämä. Työruumis jälkiteollisessa taloudessa [Embodiment and Working Life. Working Body in Post-Industrial Economy], Tampere: Vastapaino.

Persson, A. (2011). Changing Boundaries, Defending Boundaries. Gender Relations in the Swedish Armed Forces, Linköping: Linköping University. http://urn.kb.se/resolve?urn= urn $\% 3$ Anbn $\% 3$ Ase $\% 3$ Aliu \%3Adiva-71257.

Rones, N., \& Fasting, K. (2017). Theorizing Military Masculinities and National Identities: The Norwegian Experience. In R. Woodward \& C. Duncanson (Eds.) The Palgrave International Handbook of Gender and the Military. (pp. 145-162), London: Palgrave Macmillan. https://doi.org/10.1057/978-1-137-51677-0 9

Sasson-Levy, O. (2003). Feminism and military gender practices: Israeli women soldiers in 'Masculine' Roles, Sociological Inquiry 73(3): 440-465. https://doi.org/10.1111/1475-682x. 00064.

Sasson-Levy, O. (2008). Individual bodies, collective state interests: the case of Israeli combat soldiers, Men and Masculinities 10(3): 296-321. https://doi.org/10.1177/ 1097184x06287760.

Sløk-Andersen, B. (2018). The Becoming of Good Soldiers. An Ethnographic Exploration of Gender and Other Obstacles in the Military Borderland, Copenhagen: University of Copenhagen. https://research-api.cbs.dk/ws/portalfiles/portal/58400870/Beate Sl k Andersen.pdf.

Steidl, C. R., \& Brookshire, A. R. (2019). Just one of the guys until shower time: how symbolic embodiment threatens women's inclusion in the US military, Gender, Work and Organization 26: 1271-1288. https://doi.org/10.1111/gwao.12320. 
Tuomi, J., \& Sarajärvi, A. (2009). Laadullinen tutkimus ja sisällönanalyysi [Qualitative Research and Content Analysis], Helsinki: Tammi.

Vaara, J., Viskari, J., Kyröläinen, H., \& Santtila, M. (2016). Naissotilaiden mielipiteitä ja kokemuksia fyysisestä kunnosta sekä kuntotestien suoritusvaatimuksista Puolustusvoimissa [Female Soldiers' Opinions and Experiences on Physical Fitness and Performance Requirements in Fitness Tests in the Defence Forces], Helsinki: Pääesikunta.

Via, S. (2010). Gender, Militarism, and Globalization: Soldiers for Hire and Hegemonic Masculinity. In L. Sjoberg \& S. Via (Eds.) Gender, War and Militarism. Feminist Perspectives. (pp. 42-53), Santa Barbara, California: Praeger Security International.

Warhurst, C., \& Nickson, D. (2009). 'Who's got the look?' Emotional, aesthetic and sexualized labour in interactive services, Gender, Work and Organization 16(3): 385-404. https://doi.org/10.1111/j.1468-0432.2009.00450.x.

World Economic Forum. (2019). Global Gender Gap Report 2020, Geneva: World Economic Forum. https://www.weforum.org/reports/gender-gap-2020-report-100-years-pay-equality. 